\title{
Effect of urea and molasses supplementation on quality of cassava top silage
}

\author{
S. Kang ${ }^{1}$, M. Wanapat ${ }^{2,3}$ and A. Nunoi ${ }^{2}$ \\ ${ }^{1}$ National Institute of Education, Phnom Penh, Cambodia \\ ${ }^{2}$ Khon Kaen University, Tropical Feed Resources Research and Development Center (TROFREC), \\ Faculty of Agriculture, Department of Animal Science, Khon Kaen 40002, Thailand
}

KEY WORDS: Manihot esculenta, cassava top silage, molasses, nutritive value, urea, in vitro gas production

Received: $\quad 2$ June 2017

Revised: 8 December 2017

Accepted: 26 February 2018
${ }^{3}$ Corresponding author:

e-mail: metha@kku.ac.th

\begin{abstract}
The aim of the study was to evaluate the nutritive value and fermentation efficiency of cassava top silage using in vitro gas production technique. The four-month plants were harvested, chopped into $2-3 \mathrm{~cm}$ pieces and ensiled with $0,0.5$ and $1 \%$ urea $(U)$, and $0,0.5,1$ and $2 \%$ molasses (M) (on the basis of the crop dry matter (DM)). Silage $\mathrm{pH}$ increased with $\mathrm{U}$ supplementation but decreased by addition of $2 \%$ of $\mathrm{M}$, so the lowest $\mathrm{pH}$ values were observed in: UOM0-2 and then in U0.5M2 and U1M2 groups. The $U$ supplementation increased crude protein content in cassava top silage in a dose-dependent manner. There was observed $U \times M$ interaction for neutral and acid detergent fibre contents (NDF and ADF, respectively) - when added together the $\mathrm{M}$ decreased these parameters in a dose-dependent manner, and the lowest value of NDF was observed in U1M2 group, and of ADF - for U0M2, U0.5M2 and U1M2 groups. The cumulative gas production was increased when either $\mathrm{U}$ or $\mathrm{M}$ were added, and the highest value was observed in U0.5M2 and U1M2 groups. In addition, the true digestibility was increased when $\mathrm{M}$ was added and the NDF digestibility was the highest in M2 groups. Fermented pH was increased by $U$ supplementation while protozoa populations were similar among treatments. So, supplementation with $0.5-1 \%$ of $U$ and $2 \%$ of $M$ may increase cassava top silage quality and the in vitro fermentation efficiency. However studies evaluating cassava top silage influence on animal growth performance are recommended.
\end{abstract}

\section{Introduction}

An annual crop, cassava (Manihot esculenta, Crantz), is mainly cultivated in the tropical and subtropical regions especially for its starchy tuberous roots from which tapioca is mainly produced. To grow, it needs only sandy-loam soils, low rainfall and high temperature (Wanapat and Kang, 2013, 2015). The plant is built of, \%: leaves 6 , stem 44 and roots 50 (Balagopalan, 2001). Apart from the root, cassava leaves and stem are a good source of dry matter $(\mathrm{DM})$ - at the time of root harvesting the green parts of plant constitute $4.6 \mathrm{t} \mathrm{DM}$ per ha. In Thailand, a hay made from cassava foliage has been used successfully as a source of ruminally undegraded protein with a high content of digestible nutrients. Such a hay was willingly eaten by ruminants not only as a sole feed but also as an additive to diets based on crop residues such as urea treated straw and sugarcane tops (Wanapat and Kang, 2013).

It is widely known that forage conservation plays a pivotal role in productive and efficient ruminant livestock production. From the 1960s the amounts of produced silage are increasing and this 
method of forage preservation in temperate regions of the world is predominant (Cheli et al., 2013). Due to forage conservation a better supply of quality feed is guaranteed in case of low forage production. Only high quality silage fed to animals can sustain animal health and reduce the cost of production, so the efforts to minimize the quality losses during preservation are still made (Bartzanas et al., 2013). Ensiling is a method based on natural lactic acid fermentation under anaerobic conditions (Ki et al., 2009). To improve this process, silage additives such as chemicals, enzymes and bacterial agents can be used. Addition of carbon and nitrogen sources may positively affect the silage quality and, consequently, improve rumen degradation and animal production. Sufficient amount of fermentable carbohydrates in plant material is necessary for lactic acid production which reduces fermentation $\mathrm{pH}$ and guarantees the good quality silage (McDonald et al., 2011). Low water soluble carbohydrate content may be the main cause of low quality silage. According to Humphreys (1991) and Yokota et al. (1992), molasses (M) is often added to silage as a sugar additive increasing fermentation and feed quality. The faster the fermentation is completed, the more nutrients will be present in the silage. Adding urea (U) is a common and cheap method of increasing nitrogen supply; however, $\mathrm{U}$ decreases the fermentation quality of silage by increasing $\mathrm{pH}$ with the release of ammonia (Pancholy et al., 1994). So, it is considered that the addition of different combinations of $\mathrm{U}$ and $\mathrm{M}$ may improve both the protein content and fermentation quality of the silage. It was found that supplementation of $U$ and $M$ could improve the quality of whole crop rice silage (addition of $1.5 \%$ of U and 3-4\% of M; Wanapat et al., 2013, 2014), Leucaena leucocephala silage (addition of $1 \%$ of $\mathrm{U}$ and $2 \%$ of M; Giang et al., 2016; Phesatcha and Wanapat, 2016) and Napiergrass silage (addition of $0.6 \%$ of $\mathrm{U}$ and $5 \%$ of M; Yunus et al., 2000) in terms of nutritive value, nutrient digestibility and rumen fermentation efficiency; therefore, such supplementation may increase performance of beef cattle and lactating dairy cows.

In vitro fermentation technique is less expensive and less time-consuming than in vivo method, and it also allows to maintain experimental conditions more precisely (Getachew et al., 1998). Therefore, the objective of this in vitro study was to determine the effect of $U$ and $M$ supplementation into cassava top silage (CTS) on silage quality, gas production, digestibility and fermentation efficiency.

\section{Material and methods}

\section{Cassava top silage}

Four-month cassava top was harvested and immediately chopped into $2-3 \mathrm{~cm}$ pieces and ensiled with $\mathrm{U}$ at doses of $0,0.5$ and $1 \%$ (U0, U0.5 and $\mathrm{U} 1$, respectively), and $\mathrm{M}$ at doses of $0,0.5,1$ and $2 \%$ (M0, M0.5, M1 and M2, respectively) on the basis of crop dry matter (DM). Cassava top was mixed with $\mathrm{M}$ and $\mathrm{U}$, and then packed into plastic bags. The silage bags were kept in ambient temperature (about $25-30{ }^{\circ} \mathrm{C}$ ). All treatment combinations were performed in triplicates at $1 \mathrm{~kg}$ each. After 30 days of ensiling, $\mathrm{pH}$ and temperature of each silage were measured using a portable $\mathrm{pH}$ and temperature meter (HI-8424, HANNA Instruments, Woonsocket, RI, USA). Approximately $200 \mathrm{~g}$ of each silage were sampled for analysis of chemical composition. The one part of sample was used for DM analysis, the second - was dried at $60{ }^{\circ} \mathrm{C}$ for $48 \mathrm{~h}$ and ground to pass through a $1-\mathrm{mm}$ sieve in the feed mill using Foss Tecator Cyclotec Sample Mill (fisher scientific part of Thermo Fisher Scientific, Waltham, MA, USA) for analysis of DM, organic matter (OM) and crude protein (CP) (AOAC International, 2012), and acid detergent fibre (ADF) and neutral detergent fibre (NDF) (Van Soest et al., 1991).

\section{In vitro gas production}

In total, twenty four CTS were used in in vitro fermentation study using gas production technique. Samples of each CTS were collected, oven-dried at $60{ }^{\circ} \mathrm{C}$ for $72 \mathrm{~h}$, ground to pass through a $1-\mathrm{mm}$ sieve and prepared for in vitro study. The in vitro gas production technique was performed according to Menke et al. (1979). Strict anaerobic techniques were used in all steps during the rumen fluid transferring and incubation periods. From two rumenfistulated dairy steers $(200 \pm 15 \mathrm{~kg}$ body weight $)$ a sample of $1000 \mathrm{ml}$ of rumen fluid was collected before morning feeding into a 2-liter plastic flask and transferred into 2 pre-warmed thermos flasks (1 litter) (Menke et al., 1979; Makkar et al., 1995). The fluid was then transported to the laboratory. Samples of each silage $(200 \mathrm{mg})$ were weighed into 60 -ml glass bottles which were then sealed with rubber stoppers and aluminium caps. All bottles were pre-warmed in a water bath at $39^{\circ} \mathrm{C}$ for $1 \mathrm{~h}$ before filling with $30 \mathrm{ml}$ of the rumen inocula mixture. The reducing medium was prepared according to Menke and Steingass (1988). Rumen fluid was mixed with the reducing medium at 1:2 ratio. The mixture was 
kept stirred under $\mathrm{CO}_{2}$ pumping at $39{ }^{\circ} \mathrm{C}$ using a magnetic stirrer fitted with a hot plate. Medium solution $(30 \mathrm{ml})$ was transferred into each bottle and incubated in the water bath at $39^{\circ} \mathrm{C}$.

Gas production kinetics were recorded at 1, 2, 4, $6,8,12,24,48,72,96$ and $120 \mathrm{~h}$ by extraction using glass syringes. Total gas values were corrected for blank incubation. Cumulative gas production was calculated according to Ørskov and McDonald (1979):

$$
\mathrm{y}=\mathrm{a}+\mathrm{b}\left(1-\mathrm{e}^{(-\mathrm{ct})}\right)
$$

where: $\mathrm{y}$ - gas produced at the time $\mathrm{t}, \mathrm{a}$ - gas production from immediately soluble fraction, $b-$ gas production from the insoluble fraction, $\mathrm{c}-$ gas production rate constant for the insoluble fraction (b), $\mathrm{t}$ - incubation time, $(\mathrm{a}+\mathrm{b})$ - the potential extent of gas production.

At 48 hour post inoculation, in vitro digestibility was measured based on the following equation according to Van Soest and Robertson (1985): true digestibility $(\mathrm{TD})=((\mathrm{DM}$ of feed taken for incubation - NDF residue) $\times 100$ ) $/ \mathrm{DM}$ of feed taken for incubation. The in vitro fermentation $\mathrm{pH}$ was measured at $12 \mathrm{~h}$ incubation time using a portable $\mathrm{pH}$ and temperature meter (HI-8424, HANNA Instruments, Woonsocket, RI, USA). The 1-ml sample of fluid was collected and kept in a plastic bottle with $9 \mathrm{ml}$ of $10 \%$ formalin solution $(1: 9 \mathrm{v} / \mathrm{v}$, rumen fluid: $10 \%$ formalin), and stored at $4{ }^{\circ} \mathrm{C}$ for the direct count of protozoa (Galyean, 2010) using a haemocytometer (Boeco, Hamburg, Germany).

The obtained data were subjected to the General Linear Model (GLM) procedures of Statistical Analysis System (SAS, 2013) according to a $3 \times 4$ factorial arrangement in a completely randomized design. The statistical units were: nutritive values of CTS, gas production, digestibility and protozoal population. The statistical model included urea level, molasses level and their interaction. For all parameters, differences among treatments were contrasted by the Tukey's multiple comparison test.

\section{Results and discussion}

It was shown that the $\mathrm{U}$ addition increased silage $\mathrm{pH}$ regardless used dose $(P<0.05$; Table 1$)$. On the other hand, silage $\mathrm{pH}$ was decreased when $2 \%$ of $\mathrm{M}$ was added $(P<0.05$; Table 1$)$ and this was in the disagreement with the study of Wanapat et al. (2013), in which no effect of M addition on whole crop rice silage $\mathrm{pH}$ was stated. The silage temperature was not affected by $\mathrm{U}$ and $\mathrm{M}$ (Table 1). According to Petterson (1988) a silage is considered
Table 1. Effect of urea (U) and molasses (M) supplementation on nutritive values of the cassava top silage

\begin{tabular}{|c|c|c|c|c|c|c|c|}
\hline Treatments & DM & $\mathrm{OM}$ & NDF & ADF & $\mathrm{CP}$ & \multirow{2}{*}{$\mathrm{pH}$} & \multirow{2}{*}{$\begin{array}{l}\text { Tempera- } \\
\text { ture, }{ }^{\circ} \mathrm{C}\end{array}$} \\
\hline U M & $\% \mathrm{DM}$ & & & & & & \\
\hline \multicolumn{8}{|l|}{$\bar{U}$} \\
\hline 0 & 18.3 & $93.3^{b}$ & $52.4^{\mathrm{a}}$ & $34.2^{\mathrm{a}}$ & $22.0^{\circ}$ & $3.4^{\mathrm{b}}$ & 31.5 \\
\hline 0.5 & 19.0 & $93.6^{\mathrm{ab}}$ & $54.0^{\mathrm{a}}$ & $31.4^{\mathrm{ab}}$ & $28.3^{b}$ & $4.6^{\mathrm{a}}$ & 31.5 \\
\hline 1 & 18.6 & $94.0^{\mathrm{a}}$ & $48.9^{b}$ & $28.2^{b}$ & $32.5^{a}$ & $4.7^{\mathrm{a}}$ & 31.5 \\
\hline SEM & 1.49 & 0.28 & 1.85 & 2.29 & 1.65 & 0.18 & 0.48 \\
\hline$P$-value & ns & ** & $* *$ & * & $* * *$ & * & ns \\
\hline
\end{tabular}

$\mathrm{M}$

$\begin{array}{lllllllll} & 0 & 18.2 & 94.3^{\mathrm{a}} & 60.2^{\mathrm{a}} & 36.9^{\mathrm{a}} & 27.0 & 4.5^{\mathrm{a}} & 31.5 \\ & 0.5 & 20.1 & 93.6^{\mathrm{b}} & 58.0^{\mathrm{a}} & 32.7^{\mathrm{b}} & 28.1 & 4.2^{\mathrm{a}} & 31.5 \\ 1 & 17.4 & 93.5^{\mathrm{b}} & 49.3^{\mathrm{b}} & 28.4^{\mathrm{c}} & 27.1 & 4.3^{\mathrm{a}} & 31.5 \\ & 2 & 18.9 & 93.1^{\mathrm{b}} & 39.7^{\mathrm{c}} & 27.1^{\mathrm{c}} & 28.2 & 3.9^{\mathrm{b}} & 31.5 \\ \text { SEM } & 1.44 & 0.24 & 2.54 & 1.68 & 2.89 & 0.06 & 0.50 \\ P \text {-value } & \text { ns } & { }^{* *} & { }^{* * *} & * * * & \text { ns } & * & \text { ns }\end{array}$

$\mathrm{U} \times \mathrm{M}$

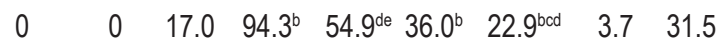

$\begin{array}{lllllllll}0 & 0.5 & 21.5 & 93.2^{\mathrm{e}} & 64.7^{\mathrm{b}} & 36.7^{\mathrm{b}} & 21.9^{\mathrm{cd}} & 3.2 & 31.5\end{array}$

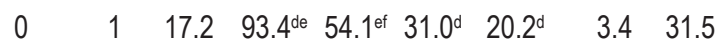

$\begin{array}{llllllllll}0 & 2 & 17.4 & 92.3^{\mathrm{f}} & 36.0^{\mathrm{j}} & 33.1^{\mathrm{c}} & 23.0^{\mathrm{abcd}} & 3.2 & 31.5\end{array}$

$\begin{array}{lllllllll}0.5 & 0 & 19.3 & 93.8^{\mathrm{c}} & 67.8^{\mathrm{a}} & 39.5^{\mathrm{a}} & 27.1^{\mathrm{abcd}} & 4.9 & 31.5\end{array}$

$\begin{array}{lllllllll}0.5 & 0.5 & 20.1 & 93.3^{\text {de }} & 58.1^{c} & 32.6^{\text {dc }} & 29.5^{\text {abcd }} & 4.7 & 31.5\end{array}$

$\begin{array}{llllllllll}0.5 & 1 & 17.1 & 93.7^{c} & 48.6^{9} & 28.4^{\mathrm{e}} & 27.5^{\mathrm{abcd}} & 4.7 & 31.5\end{array}$

$\begin{array}{lllllllll}0.5 & 2 & 19.5 & 93.6^{\mathrm{dc}} & 41.5^{\mathrm{i}} & 25.2^{\mathrm{f}} & 29.1^{\mathrm{abcd}} & 4.0 & 31.5\end{array}$

$\begin{array}{lllllllll}1 & 0 & 18.1 & 94.7^{\mathrm{a}} & 57.8^{\mathrm{cd}} & 35.2^{\mathrm{b}} & 31.1^{\mathrm{abc}} & 4.8 & 31.5\end{array}$

$\begin{array}{lllllllll}1 & 0.5 & 18.5 & 94.2^{\mathrm{b}} & 51.1^{\text {fg }} & 28.9^{\mathrm{e}} & 32.9^{\mathrm{gb}} & 4.7 & 31.5\end{array}$

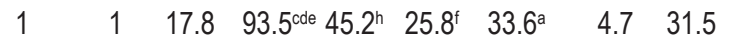

$\begin{array}{lllllllll}1 & 2 & 19.8 & 93.4^{\text {de }} & 41.6^{\mathrm{i}} & 23.0^{\mathrm{g}} & 32.4^{\mathrm{abc}} & 4.4 & 31.5\end{array}$

$\begin{array}{llllllll}\text { SEM } & 1.73 & 0.06 & 0.06 & 0.74 & 0.37 & 0.89 & 0.64\end{array}$

$P$-value ns *** ${ }^{* * *}{ }^{* * *}{ }^{* * *}$ ns ns

DM - dry matter; OM - organic matter; $C P$ - crude protein; ADF - acid detergent fibre; NDF - neutral detergent fibre; $P$-value: ${ }^{*}-P<0.05$, ${ }^{* *}-P<0.01,{ }^{* *}-P<0.001$; ns - non significant; ${ }^{a-j}-$ means with different superscripts are significantly different according to Tuckey's test (presented only if $P$-value for main effects ( $U$ or $M$ ) or interaction was significant)

to be of high quality when the $\mathrm{pH}$ is below 4.5 . In the present study such values were observed in groups U0M0-2, U0.5M2 and U1M2. However, it was found that when the fermented silage $\mathrm{pH}$ is 4.3 or even below, the limitation of proteolytic bacteria activities is possible, and so it is the most preferred silage process for protein lose prevention (Man and Wiktorsson, 2002). The $\mathrm{pH}$ values of each CTS in the present study were similar to the values reported by Man and Wiktorsson (2002) and Oni et al. (2014). Moreover, lower $\mathrm{pH}$ of silage could resulted from higher lactic acid concentration in those silages. Cao et al. (2009) stated that lactic acid is the strongest acid in the silage, and its presence will decrease $\mathrm{pH}$ more effectively than other volatile fatty acids (VFAs). 
Plant sugars are the substrates for the fermentation process, so that their concentration in the parent forage has a major influence on the extent and type of the fermentation in the silage. It appears that high water soluble carbohydrate concentration in the fresh forage gives a high probability of obtaining lactate type silage that is known as well preserved (Wilkinson, 1983). The addition of soluble carbohydrate may improve the quality of silage and further additives are used to overcome a low content of sugars in tropical grasses. Therefore, $\mathrm{M}$ is frequently used in silage making as a source of soluble carbohydrate. The U supplementation into CTS increased $\mathrm{CP}$ content in a dose-dependent manner $(P<0.001)$, but this parameter was not influenced by the addition of $\mathrm{M}$ (Table 1). In the present study the CP content in CTS was reduced slightly after ensiling and the obtained values were similar to values reported by Man and Wiktorsson (2002) and Khang and Wiktorsson (2004). Energy is usually the limiting factor for growth of anaerobic microbes and addition of $\mathrm{U}$ might increase the microbial mass that leads to increased CP content (Staples et al., 1981). The provision of carbon skeleton and energy for microbial growth might have synchronized with ammonia released from urea hydrolysis, consequently increasing the CP content of forages ensiled (Salem et al., 2013). Moreover, when U was added to silage, the bacteria present in the rumen fluid were able to produce protein from this source of nitrogen. This nonprotein nitrogen product binds with the moisture in silage, and in the presence of adequate moisture the loss of protein content is minimal. In addition the U supplementation decreased NDF and ADF contents but only when $1 \%$ of $U$ was added $(P<0.01$ and $P<0.001$, respectively). The $\mathrm{M}$ addition also decreased the NDF and ADF ( $P<0.05$ for both), but NDF was decreased only when $1 \%$ and $2 \%$ were added and ADF was decreased regardless used dose of M. However, there were observed also interactions of $\mathrm{U} \times \mathrm{M}$ for NDF and $\mathrm{ADF}(P<0.05$ for both). So, when there was a simultaneous addition of $U$ and $M$, the $M$ decreased these parameters in a dose-dependent manner: U0.5M0 > U0.5M0.5 > $\mathrm{U} 0.5 \mathrm{M} 1>\mathrm{U} 0.5 \mathrm{M} 2$ and $\mathrm{U} 1 \mathrm{M} 0>\mathrm{U} 1 \mathrm{M} 0.5>\mathrm{U} 1 \mathrm{M} 1>$ U1M2 (no such effect was observed in U0 groups). The lowest value of NDF was observed for U1M2 group, and of ADF - for U0M2, U0.5M2 and U1M2 groups. There was an interaction effect of $\mathrm{M}$ and $\mathrm{U}$ also on OM and CP content of CTS (Table 1). Wanapat et al. (2013) also reported that supplementation of $U$ and $\mathrm{M}$ improved the quality of whole crop rice silage by increasing $\mathrm{CP}$ and reducing NDF and ADF contents. This may indicate that combination of $\mathrm{U}$ and $\mathrm{M}$ may enhance the quality of the CTS.

Gas production from the insoluble fraction (b), gas potential extent of gas production $(\mathrm{a}+\mathrm{b})$ and $\mathrm{cu}-$ mulative gas production at $120 \mathrm{~h}$ were increased by $\mathrm{U}$ supplementation regardless used dose $(P<0.001$ for all three parameters; Table 2$)$. The $\mathrm{M}$ supplementation increased $(b)$ value $(P<0.001)$ regardless

Table 2. Effect of urea $(U)$ and molasses $(M)$ supplementation into cassava top silage on in vitro gas production

\begin{tabular}{|c|c|c|c|c|c|c|}
\hline \multicolumn{2}{|c|}{ Treatments } & \multicolumn{5}{|c|}{ Gas production kinetics, $\mathrm{ml} \cdot 0.1 \mathrm{~g}^{-1}$} \\
\hline U & $\mathrm{M}$ & a & $\mathrm{b}$ & c & $a+b$ & Gas $(120 \mathrm{~h})$ \\
\hline \multicolumn{7}{|l|}{ U } \\
\hline 0 & & $-0.8^{\mathrm{b}}$ & $46.0^{\mathrm{b}}$ & $0.040^{\mathrm{a}}$ & $45.1^{\mathrm{b}}$ & $44.8^{b}$ \\
\hline 0.5 & & $2.9^{\mathrm{a}}$ & $65.2^{\mathrm{a}}$ & $0.037^{b}$ & $68.1^{\mathrm{a}}$ & $67.3^{\mathrm{a}}$ \\
\hline 1 & & $2.8^{\mathrm{a}}$ & $63.0^{\mathrm{a}}$ & $0.039^{\mathrm{ab}}$ & $65.9^{\mathrm{a}}$ & $65.3^{\mathrm{a}}$ \\
\hline SEM & & 1.46 & 4.83 & 0.001 & 4.39 & 4.41 \\
\hline$P$-valu & & ** & $* * *$ & * & $* * *$ & $* * *$ \\
\hline \multicolumn{7}{|l|}{ M } \\
\hline & 0 & $3.1^{\mathrm{a}}$ & $45.4^{b}$ & $0.036^{c}$ & $48.5^{b}$ & $47.8^{\mathrm{b}}$ \\
\hline & 0.5 & $1.5^{b}$ & $57.3^{\mathrm{a}}$ & $0.038^{b}$ & $58.8^{\mathrm{ab}}$ & $58.2^{\mathrm{ab}}$ \\
\hline & 1 & $1.7^{\mathrm{b}}$ & $62.9^{\mathrm{a}}$ & $0.041^{a}$ & $64.6^{\mathrm{a}}$ & $64.1^{\mathrm{a}}$ \\
\hline & 2 & $0.3^{b}$ & $66.6^{\mathrm{a}}$ & $0.041^{a}$ & $66.9^{\mathrm{a}}$ & $66.4^{\mathrm{a}}$ \\
\hline SEM & & 0.61 & 5.03 & 0.0001 & 5.84 & 5.75 \\
\hline$P$-valu & & * & $* * \star$ & $* * *$ & * & $* *$ \\
\hline \multicolumn{7}{|l|}{$U \times M$} \\
\hline 0 & 0 & $3.3^{a b c}$ & 30.6 & $0.038^{c}$ & 33.9 & 33.5 \\
\hline 0 & 0.5 & $-2.1^{\text {de }}$ & 44.8 & $0.040^{a b c}$ & 42.7 & 42.3 \\
\hline 0 & 1 & $-2.9^{e}$ & 54.8 & $0.042^{\mathrm{a}}$ & 51.9 & 51.5 \\
\hline 0 & 2 & $-1.5^{\text {ed }}$ & 53.6 & $0.042^{\mathrm{a}}$ & 52.1 & 51.8 \\
\hline 0.5 & 0 & $4.0^{\mathrm{abc}}$ & 52.6 & $0.032^{\mathrm{d}}$ & 56.7 & 55.6 \\
\hline 0.5 & 0.5 & $5.1^{\mathrm{ab}}$ & 64.1 & $0.038^{c}$ & 69.2 & 68.5 \\
\hline 0.5 & 1 & $2.0^{\mathrm{abcd}}$ & 71.1 & $0.040^{a b c}$ & 73.1 & 72.5 \\
\hline 0.5 & 2 & $0.3^{\text {cde }}$ & 73.0 & $0.040^{\mathrm{abc}}$ & 73.4 & 72.7 \\
\hline 1 & 0 & $1.8^{\mathrm{abcd}}$ & 53.1 & $0.039^{b c}$ & 54.9 & 54.3 \\
\hline 1 & 0.5 & $1.5^{\mathrm{bcd}}$ & 63.0 & $0.039^{b c}$ & 64.5 & 63.9 \\
\hline 1 & 1 & $6.0^{\mathrm{a}}$ & 62.9 & $0.040^{\mathrm{ab}}$ & 68.9 & 68.4 \\
\hline 1 & 2 & $2.0^{\mathrm{abcd}}$ & 73.2 & $0.040^{a b c}$ & 75.3 & 74.7 \\
\hline SEM & & 1.12 & 2.26 & 0.0004 & 2.46 & 1.09 \\
\hline$P$-valu & & * & ns & * & ns & ns \\
\hline
\end{tabular}

$a$ - gas production from the immediately soluble fraction; $b$ - gas production from the insoluble fraction; $c$ - gas production rate constant for the insoluble fraction (b); $a+b-$ gas potential extent of gas production; $P$-value: ${ }^{*}-P<0.05,{ }^{* *}-P<0.01,{ }^{* * *}-P<0.001$, ns - non significant; ${ }^{a-e}$ - means with different superscripts are significantly different according to Tuckey's test (presented only if $P$-value for main effects ( $U$ or $M$ ) or interaction was significant)

used dose, and $(\mathrm{a}+\mathrm{b})$ and cumulative gas production at $120 \mathrm{~h}$ were increased only in M1 and M2 groups in comparison to $\mathrm{M} 0(P<0.05$ and $P<0.01$, respectively). So, the highest values for all these 3 parameters were observed in U0.5M2 and U1M2. Gas production from the immediately soluble fraction (a) was increased by $\mathrm{U}$ supplementation $(P<0.01)$ but it was 
reduced when $\mathrm{M}$ was added $(P<0.05)$. However, when $\mathrm{M}$ was supplemented simultaneously with $\mathrm{U}$ $(P<0.05$ for interaction), its addition decreased (a) value only in $\mathrm{U} 0.5 \mathrm{M} 2$ vs $\mathrm{U} 0.5 \mathrm{M} 0$, and when $1 \%$ of $U$ was added the difference was observed only between U1M0.5 and U1M1 with higher value in U1M1 group. Furthermore, the gas production rate constant for the insoluble fraction $\mathrm{b}$ (c) was lower in U0.5 in comparison to U0 treatment $(P<0.05)$ and higher in $\mathrm{M}$ supplemented groups $(P<0.001)$. However when $\mathrm{U}$ and $\mathrm{M}$ were added simultaneously $(P<0.05$ for interaction), the increasing effect of $\mathrm{M}$ was observed only when $0.5 \%$ of $\mathrm{U}$ was added. The increasing of gas production kinetics may result from the addition of $U$ to the silage which could improve rumen fermentation and nutrient digestibility (Cherdthong et al., 2011; Sweeny et al., 2014).

Table 3. Effect of urea (U) and molasses (M) supplemented into cassava top silage on in vitro digestibility, $\mathrm{pH}$ and protozoal population

\begin{tabular}{|c|c|c|c|c|c|}
\hline \multicolumn{2}{|c|}{ Treatments } & \multicolumn{2}{|c|}{ Digestibility, \% } & \multirow{2}{*}{$\mathrm{pH}$} & \multirow{2}{*}{$\begin{array}{l}\text { Protozoa, } \\
\text { cell/ml }\left(\times 10^{5}\right)\end{array}$} \\
\hline $\mathrm{U}$ & $M$ & true & NDF & & \\
\hline \multicolumn{6}{|l|}{$\bar{U}$} \\
\hline 0 & & 64.1 & 41.6 & $6.65^{b}$ & 3.0 \\
\hline 0.5 & & 69.6 & 43.6 & $6.74^{\mathrm{a}}$ & 2.4 \\
\hline 1 & & 67.7 & 48.1 & $6.70^{\mathrm{a}}$ & 2.6 \\
\hline SEM & & 4.21 & 3.65 & 0.02 & 0.57 \\
\hline$P$-valt & & ns & ns & $* *$ & $\mathrm{~ns}$ \\
\hline
\end{tabular}

$\begin{array}{llccll}P \text {-value } & & \text { ns } & \text { ns } & { }^{* *} & \text { ns } \\ \text { M } & & & & & \\ & 0 & 57.1^{\mathrm{b}} & 36.6^{\mathrm{c}} & 6.69 & 3.2 \\ & 0.5 & 68.0^{\mathrm{a}} & 43.5^{\mathrm{b}} & 6.71 & 2.3 \\ & 1 & 71.0^{\mathrm{a}} & 45.1^{\mathrm{b}} & 6.68 & 2.3 \\ & 2 & 72.3^{\mathrm{a}} & 52.5^{\mathrm{a}} & 6.69 & 2.9 \\ \text { SEM } & & 2.90 & 2.39 & 0.03 & 0.53 \\ P \text {-value } & & * * * & * * * & \mathrm{~ns} & \mathrm{~ns}\end{array}$

\begin{tabular}{clllll}
$U \times M$ & & & & & \\
0 & 0 & 50.1 & 32.2 & 6.61 & 4.0 \\
0 & 0.5 & 68.3 & 39.4 & 6.68 & 2.5 \\
0 & 1 & 68.5 & 40.2 & 6.65 & 2.3 \\
0 & 2 & 69.3 & 54.4 & 6.65 & 3.3 \\
0.5 & 0 & 64.3 & 36.5 & 6.75 & 3.0 \\
0.5 & 0.5 & 70.3 & 44.3 & 6.74 & 2.3 \\
0.5 & 1 & 71.1 & 44.6 & 6.73 & 2.5 \\
0.5 & 2 & 72.5 & 49.0 & 6.71 & 2.0 \\
1 & 0 & 56.9 & 41.0 & 6.71 & 2.5 \\
1 & 0.5 & 65.3 & 46.8 & 6.71 & 2.3 \\
1 & 1 & 73.3 & 50.5 & 6.67 & 2.3 \\
1 & 2 & 75.2 & 54.0 & 6.69 & 3.5 \\
SEM & & 0.31 & 2.05 & 0.03 & 0.63 \\
$P$-value & & ns & ns & ns & ns \\
\hline PF
\end{tabular}

NDF - neutral detergent fibre; $P$-value: ${ }^{*}-P<0.05,{ }^{* *}-P<0.01$, ${ }^{* * *}-P<0.001$, ns - non significant; ${ }^{a b c}-$ means with different superscripts are significantly different according to Tuckey's test (presented only if $P$-value for main effects $(\mathrm{U}$ or $\mathrm{M})$ or interaction was significant)
Only the $\mathrm{M}$ supplementation affected in vitro true and NDF digestibilities $(P<0.05$ for both parameters; Table 3$)$. The true digestibility was increased regardless $\mathrm{M}$ dose $(\mathrm{M} 0.5=\mathrm{M} 1=\mathrm{M} 2)$, and the NDF digestibility was the highest in M2 group. The lack of $\mathrm{U}$ influence on in vitro true and NDF digestibilities is rather surprising as it is supposed that rumen fermentation and digestibility increases with the $U$ supplementation due to the increased rumen microorganisms growth rate as there is more available $\mathrm{N}$ in the form of ammonia from the urea hydrolysis (Khattab et al., 2013; Kang et al., 2015). Moreover, Wanapat et al. (2013) found that supplementation of $U$ and $M$ could increase rumen degradability of whole crop rice silage. In the present study fermented $\mathrm{pH}$ was increased by $\mathrm{U}$ supplementation $(P<0.01)$ while protozoa populations were similar among treatments (Table 3). Van Soest (1994) concluded that $\mathrm{U}$ supplementation increased ruminal $\mathrm{pH}$ post feeding as it is hydrolysed by microbial ureases into $\mathrm{CO}_{2}$ and ammonia. Therefore, the presence of $\mathrm{U}$ in CTS can be treated as $\mathrm{NH}_{3}$ source which can work as $\mathrm{pH}$ regulating rumen buffer.

\section{Conclusions}

The supplementation of $0.5 \%$ or $1 \%$ of urea with simultaneous addition of $2 \%$ of molasses may increase cassava top silage (CTS) quality, gas production and in vitro digestibility, and so could be recommended for silage preparation. However further studies evaluating CTS influence on animal performance and fattening are recommended.

\section{Acknowledgements}

Authors are very grateful to Tropical Feed Resources Research and Development Center (TROFREC), Department of Animal Science, Faculty of Agriculture, Khon Kaen University, Khon Kaen, Thailand, and the Thailand Research Fund (TRF) through the International Research Network (IRN) programme for their kind support.

\section{References}

AOAC International, 2012. Official Methods of Analysis of AOAC International. $19^{\text {th }}$ Edition. Gaithersburg, MD (USA)

Balagopalan C., 2001. Cassava utilization in food, feed and industry. In: R.J. Hillocks, J.M. Thresh, A.C. Bellotti (Editors). Cassava: Biology,ProductionandUtilization.CABIPublishing. Wallingford (UK), pp. 301, https://doi.org/10.1079/9780851995243.0000 
Bartzanas T., Bochtis D.D., Green O., Sørensen C.G., Fidaros D., 2013. Prediction of quality parameters for biomass silage: $A$ CFD approach. Comput. Electron. Agric. 93, 209-216, https:// doi.org/10.1016/j.compag.2012.05.013

Cao Y., Takahashi T., Horiguchi K.-i., 2009. Effects of addition of food by-products on the fermentation quality of a total mixed ration with whole crop rice and its digestibility, preference, and rumen fermentation in sheep. Anim. Feed Sci. Technol. 151, 1-11, https://doi.org/10.1016/j.anifeedsci.2008.10.010

Cheli F., Campagnoli A., Dell'Orto V., 2013. Fungal populations and mycotoxins in silages: From occurrence to analysis. Anim. Feed Sci. Technol. 183, 1-16, https://doi.org/10.1016/j.anifeedsci.2013.01.013

Cherdthong A., Wanapat M., Wachirapakorn C., 2011. Influence of urea calcium mixture supplementation on ruminal fermentation characteristics of beef cattle fed on concentrates containing high levels of cassava chips and rice straw. Anim. Feed Sci. Technol. 163, 43-51, https://doi.org/10.1016/j.anifeedsci.2010.10.003

Galyean M.L., 2010. Laboratory Procedures in Animal Nutrition Research. Texas Tech University. Lubbock, TX (USA), available from: https://www.depts.ttu.edu/afs/home/mgalyean/ lab_man.pdf (accessed 2018-01-18)

Getachew G., Blümmel M., Makkar H.P.S., Becker K., 1998. In vitro gas measuring techniques for assessment of nutritional quality of feeds: a review. Anim. Feed Sci. Technol. 72, 261-281, https://doi.org/10.1016/S0377-8401(97)00189-2

Giang N.T.T., Wanapat M., Phesatcha K., Kang S., 2016. Level of Leucaena leucocephala silage feeding on intake, rumen fermentation, and nutrient digestibility in dairy steers. Trop. Anim. Health Prod. 48, 1057-1064, https://doi.org/10.1007/ s11250-016-1060-3

Humphreys L.R., 1991. Tropical Pasture Utilization. Cambridge University Press. New York, NY (USA), pp. 143-148, https://doi. org/10.1017/CBO9780511525810

Khang D.N., Wiktorsson H., 2004. Effects of fresh cassava tops on rumen environment parameters, thyroid gland hormones and liver enzymes of local yellow cattle fed urea-treated fresh rice straw. Trop. Anim. Health Prod. 36, 751-762, https://doi. org/10.1023/B:TROP.0000045957.20511.ee

Kang S., Wanapat M., Phesatcha K., Norrapoke T., 2015. Effect of protein level and urea in concentrate mixture on feed intake and rumen fermentation in swamp buffaloes fed rice strawbased diet. Trop. Anim. Health Prod. 47, 671-679, https://doi. org/10.1007/s11250-015-0777-8

Khattab I.M., Salem A.Z.M., Abdel-Wahed A.M., Kewan K.Z., 2013. Effects of urea supplementation on nutrient digestibility, nitrogen utilization and rumen fermentation in sheep fed diets containing dates. Livest. Sci. 155, 223-229, https://doi. org/10.1016/j.livsci.2013.05.024

Ki K.S., Khan M.A., Lee W.S., Lee H.J., Kim S.B., Yang S.H., Baek K.S., Kim J.G., Kim H.S., 2009. Effect of replacing corn silage with whole crop rice silage in total mixed ration on intake, milk yield and its composition in Holsteins. Asian-Australas. J. Anim. Sci. 22, 516-519, https://doi.org/10.5713/ajas.2009.80556

Makkar H.P.S., Blümmel M., Becker K., 1995. Formation of complexes between polyvinyl pyrrolidones or polyethylene glycols and tannins, and their implication in gas production and true digestibility in in vitro techniques. Br. J. Nutr. 73, 897-913, https://doi.org/10.1079/BJN19950095

Man N.V., Wiktorsson H., 2002. Effect of molasses on nutritional quality of cassava and gliricidia tops silage. Asian-Australas. J. Anim. Sci. 15, 1294-1299, https://doi.org/10.5713/ajas.2002.1294

McDonald P., Edwards R.A., Greenhalgh J.F.D., Morgan C.A., Sinclair L.A., Wilkinson R.G., 2011. Animal Nutrition. $7^{\text {th }}$ Edition. Prentice Hall, New York, NY (USA)
Menke K.H., Raab L., Salewski A., Steingass H., Fritz D., Schneider W., 1979. The estimation of the digestibility and metabolizable energy content of ruminant feedingstuffs from the gas production when they are incubated with rumen liquor in vitro. J. Agric. Sci. 93, 217-222, https://doi.org/10.1017/ S0021859600086305

Menke K.H., Steingass H., 1988. Estimation of the energetic feed value obtained from chemical analysis and gas production using rumen fluid. Anim. Res. Dev. 28, 7-55

Oni A.O., Sowande O.S., Oni O.O., Aderinboye R.Y., Dele P.A., Ojo V.O.A., Arigbede O.M., Onwuka C.F.I., 2014. Effect of additives on fermentation of cassava leaf silage and ruminal fluid of West African dwarf goats. Arch. Zootec. 243, 449-459, https://doi.org/10.4321/S0004-05922014000300006

Ørskov E.R., McDonald I., 1979. The estimation of protein degradability in the rumen from incubation measurements weighted according to rate of passage. J. Agric. Sci. 92, 499-503, https:// doi.org/10.1017/S0021859600063048

Pancholy R., Mali P.C., Mathur D., 1994. Effect of urea-molasses and lactic culture on silage fermentation of Cenchrus ciliaris. Ann. Arid. Zone 33, 147-150

Petterson K., 1988. Ensiling of forages: Factors affecting silage fermentation and quality. Dissertation. Swedish University of Agricultural Science. Uppsala (Sweden)

Phesatcha K., Wanapat M., 2016. Improvement of nutritive value and in vitro ruminal fermentation of Leucaena silage by molasses and urea supplementation. Asian-Australas. J. Anim. Sci. 29, 1136-1144, https://doi.org/10.5713/ajas.15.0591

Salem A.Z.M., Zhou C.-S., Tan Z.-I., Mellado M., Salazar M.C., Elghandopur M.M.M.Y., Odongo N.E., 2013. In vitro ruminal gas production kinetics of four fodder trees ensiled with or without molasses and urea. J. Integr. Agric. 12, 1234-1242, https:// doi.org/10.1016/S2095-3119(13)60438-4

SAS (Statistical Analysis System), 2013. User's Guide: Statistic, Version $9.4^{\text {th }}$ Edition. SAS Inst. Inc., Cary, NC (USA)

Staples C.R., Fahey G.C. Jr, Rindsig R.B., Berger L.L., 1981. Evaluation of dairy waste fiber as a roughage source for ruminants. J. Dairy Sci. 64, 662-671, https://doi.org/10.3168/jds.S00220302(81)82627-6

Sweeny J.P.A., Surridge V., Humphry P.S., Pugh H., Mamo K., 2014. Benefits of different urea supplementation methods on the production performances of Merino sheep. Vet. J. 200, 398-403, https://doi.org/10.1016/j.tvjl.2014.04.003

Van Soest P.J., 1994. Nutritional Ecology of the Ruminant. $2^{\text {nd }}$ Edition. Cornell University Press. Ithaca, NY (USA)

Van Soest P., Robertson J.B., 1985. Analysis of Forages and Fibrous Foods: a Laboratory Manual for Animal Science, No 613. Cornell University Press. Ithaca, NY (USA)

Van Soest P.J., Robertson J.B., Lewis B.A., 1991. Methods of dietary fiber, neutral detergent fiber and nonstarch polysaccharides in relation to animal nutrition. J. Dairy Sci. 74, 3583-3597, https://doi.org/10.3168/jds.S0022-0302(91)78551-2

Wanapat M., Kang S., 2013. Enriching the nutritive value of cassava as feed to increase ruminant productivity. J. Nutr. Ecol. Food Res. 1, 262-269, https://doi.org/10.1166/jnef.2013.1048

Wanapat M., Kang S., 2015. Cassava chip (Manihot esculenta Crantz) as an energy source for ruminant feeding. Anim. Nutr. 1, 266-270, https://doi.org/10.1016/j.aninu.2015.12.001

Wanapat M., Kang S., Khejornsart P., Pilajun R., 2013. Improvement of whole crop rice silage nutritive value and rumen degradability by molasses and urea supplementation. Trop. Anim. Health Prod. 45, 1777-1781, http://doi.org/10.1007/s11250-0130433-0 
Wanapat M., Kang S., Khejornsart P., Pilajun R., Wanapat S., 2014. Performance of tropical dairy cows fed whole crop rice silage with varying levels of concentrate. Trop. Anim. Health Prod. 46, 185-189, https://doi.org/10.1007/s11250-013-0473-5

Wilkinson J.M., 1983. Silage made from tropical and temperate crops. World Anim. Rev. 45, 36-40

Yokota H., Kim J.H., Okajima T., Ohshima M., 1992. Nutritional quality of wilted napier grass (Pennisetum purpureum Schum.) ensiled with or without molasses. Asian-Australas. J. Anim. Sci. 5, 673-679, https://doi.org/10.5713/ajas.1992.673
Yunus M., Ohba N., Shimojo M., Furuse M., Masuda Y., 2000. Effects of adding urea and molasses on napiergrass silage quality. Asian-Australas. J. Anim. Sci. 13, 15421547, https://doi. org/10.5713/ajas.2000.1542 